\title{
Biodegradation of Spilled-oil by Immobilization Microorganisms on Diatomite-based Carrier Material
}

\author{
Xiaoyue Wang $^{1}$, Shaojun Zhang ${ }^{\star^{1,2}}$ \& Chunjuan Wang ${ }^{1,2}$ \\ ${ }^{1}$ Maritime College, Shandong Jiaotong University, Weihai, Shandong, China \\ ${ }^{2}$ Weihai Center for Disease Control and Prevention, Weihai, Shandong, China
}

Keywords: biodegradation; oil spill; adsorption; immobilization; microorganism

\begin{abstract}
This paper focused on research the dynamic adsorption capacity of immobilized microorganisms on diatomite-based carrier material. Several important parameters were studied, including different immobilization methods, $\mathrm{pH}$ value of cross linking agent, the influence on the physical properties and degradation effect of immobilized microspheres with various immobilization bacteria amount. The experimental results showed that direct immobilization method was better that of the other methods. After crosslinking at the temperature of $25{ }^{\circ} \mathrm{C}$ for $24 \mathrm{~h}$, the best immobilization conditions were at $\mathrm{pH}$ 5-6 in the cross-linking agent solution. The volume ratio of immobilization bacteria liquid and gel solution was 1:5. The immobilization of inorganic salts could accelerate the recovery of the activity of immobilized microorganisms, and the surface structure of the microspheres was observed before and after degradation by SEM. The highest degradation rate could reach $40 \%$ for free M4, while $70 \%$ for immobilized M4, which increased oil degradation rate over $30 \%$.
\end{abstract}

\section{Introduction}

Bioremediation technology refers to use bacteria either in natural existence or specially cultured to change the toxic and harmful pollutants into innocuous substances by microbial degradation or biotransformation in controllable conditions [1]. The characteristic of bioremediation is achieving degradation by taking advantage of free dominate bacteria. However, there still exist some disadvantages in this technology. Such as low effective concentration of degrading bacteria per unit volume, easy loss of bacteria, poor resistance ability due to activity limitation by environment stresses, sensitivity to intensive changes of hydraulic conditions [2]. Immobilized microorganism technique to spilled-oil treatment has many advantages while compared to conventional suspension biological treatment technique. This technique have high treatment efficiency, stable , easy for operation, large biomass, low production of sludge, good solid-liquid separation effect, and also can be purified and maintained dominant bacteria of high efficiency [3,4]. Therefore, immobilization technology was widely used in spilled-oil treatment, especially in specific spilled-oil treatment [5]. In this research, the biodegradation bacteria (M4) screen by our research group [6] in the laboratory was immobilizaed on sodium alginate (SA) containing diatomite. After comparing the physical properties, the degradation rate of microspheres, the optimum immobilization method, immobilization conditions and degradation conditions were also studied.

\section{Materials and methods}

\section{Experimental materials.}

Degradation bacteria: degrading bacteria M4 was obtained by isolation and screening from seawater that polluted by petroleum in Penglai and Qingdao city, Shandong province. The bacteria was identified as Pseudomonas aeruginosa, Acinetobacter sp., Rhodococcus erythropolis and Bacillus. The minimal medium: $\mathrm{K}_{2} \mathrm{HPO}_{4} 5 \mathrm{~g}, \mathrm{KH}_{2} \mathrm{PO}_{4} 5 \mathrm{~g}, \mathrm{NaCl} 10 \mathrm{~g},\left(\mathrm{NH}_{4}\right) \mathrm{SO}_{4} 5 \mathrm{~g}$, $\mathrm{MgSO}_{4} \cdot 7 \mathrm{H}_{2} \mathrm{O} 2.5 \mathrm{~g}, \mathrm{CaCI}_{2}{ }^{\cdot} \mathrm{H}_{2} \mathrm{O} 0.15 \mathrm{~g}$, pH7.2-7.6, distilled water $1000 \mathrm{~mL}$. Enrichment medium: minimal medium with $0.3 \%$ pesticide residues. UV-Vis spectrophotometer; scanning electron 
microscope; GC/MS (QP2010 plus, Shimadzu, Japan).

Experimental methods.

1)Determination of saturation time for diatomite adsorption

M4 seed solution 10mL was used for centrifugation, washing, suspension and precipitation, then mixed it with $100 \mathrm{~mL}$ sterile water to become bacteria liquid with a certain concentration. Added $8 \mathrm{~g}$ diatomite into the liquid, carried out the dynamic adsorption in a shaking table at $25{ }^{\circ} \mathrm{C}$. Took out a small amount of bacteria liquid, and then filtrated every one hour. With measuring OD550 by 722s spectrophotometer, the bacterium liquid concentration was obtained according to the standard curve.

\section{2)Determination of adsorption capacity of diatomite}

Two share seed solutions $(5.0 \mathrm{~mL})$, was mixed with $50 \mathrm{~mL}$ sterile water. One share is considered as blank assay OD550, acquired the bacteria number A1. Added $8.0 \mathrm{~g}$ diatomite into the other share to make dynamic adsorption in a table at $25{ }^{\circ} \mathrm{C}$, measured the OD550 through filtration after 6 hours, obtained bacteria number $A 2$. Ignored the volume changes of bacteria liquid before and after adsorption, therefore, the calculation formula was obtained based on surface adsorption F(CFU/g) to M4 per unit mass of diatomite:

$$
F=V \times(A 1-A 2) / m
$$

Where, $\mathrm{m}$ is the mass of adsorbent ( $\mathrm{g}), \mathrm{V}$ is the volume of bacteria solution (mL), $\mathrm{A} 1, \mathrm{~A} 2$ are corresponding bacteria numbers before and after adsorption.

3)Optimization of immobilization conditions

Using SA/diatomite immobilization method to immobilize M4, took the physical properties of immobilized M4 microspheres and the degradation rate as standards to optimize immobilization conditions. pH values were set at 3, 4, 5, 6, 7 in cross-linking agent, and volumes were set at 2, 4, 6, $8,10 \mathrm{~mL}$ of immobilization bacteria solution. Saline was flushed for three times after cross-linking for 24 hours under $25^{\circ} \mathrm{C}$ using single factor analysis method.

4)Effect of inorganic salts on the immobilized microspheres

A certain concentration of bacteria M4 (5 mL) was centrifuged by $5000 \mathrm{r} / \mathrm{min}$ for 3min, respectively mixed with sterilized inorganic salt solution $(5 \mathrm{~mL})$ and aseptic water $(5 \mathrm{~mL})$ forming bacteria liquid to a certain concentration, and then prepared the immobilized microspheres according to direct immobilization method in 1.2.4. It was cultivated in sterilized inorganic salt solution with $0.3 \%$ oil on a shaking table for 5 days; acquired the comparison of degradation rate for those formulations.

5)Optimization of degradation conditions

Under the condition of $35{ }^{\circ} \mathrm{C}$, changed the value of $\mathrm{pH}(5,6,7,8,9,10)$ and salinity $(1 \%, 2 \%$, $3 \%, 4 \%, 5 \%)$. By employing single factor analysis method, added immobilized microspheres to sterilized inorganic salt solution containing $0.3 \%$ crude-oil for degradation in 5 days. Finally, the degradation rate was determined the by UV spectrophotometer method.

\section{Results and discussions}

Time of saturation when M4 was adsorbed by diatomite.

From the results (Figure 1), it could be concluded that the concentration changed fast at the first 3 $\mathrm{h}$, and the diatomite adsorption rate was relatively large. With time prolonged, the adsorption rate decreased gradually. The adsorption rate basically came to balance after $6 \mathrm{~h}$, the concentration of bacterium liquid was fundamental without a change. 


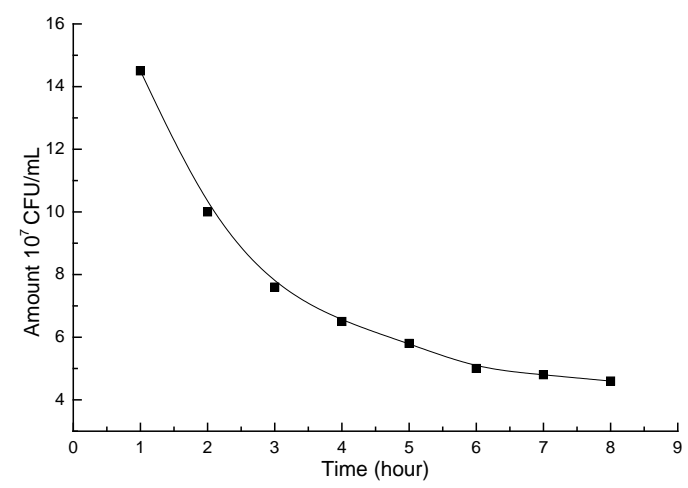

Figure 1. Bacteria concentration changes with time

\section{Calculation of adsorption effect to M4 by diatomite.}

According to the method of 1.2.3, measured the number of bacteria $A 1$ and $A 2$ which respectively represented the bacteria number before and after adsorption by activated carbon. The results (Table 1) could be obtained by the experiment that, the adsorption capacity $F$ could reach $11.1 \times 10^{8} \mathrm{CFU} / \mathrm{g}$ adsorbed by diatomite. With regard to SA/diatomite immobilization, the mechanical strength of the microspheres was increased by diatomite addition. Meanwhile, it could adsorb microorganism which further enhanced immobilization ability.

Table 1. Bacteria changes before and after adsorption with diatomite

\begin{tabular}{lll}
\hline Time (h) & $\begin{array}{l}\mathrm{OD}_{550} \\
\text { times } \\
\text { diluted })\end{array}$ & $\begin{array}{l}(10 \\
\times 10^{7} \\
\text { CFU/mL }\end{array}$ \\
\hline 0 & 0.31 & 22.33 \\
6 & 0.19 & 13.54 \\
9 & 0.16 & 12.26 \\
12 & 0.15 & 12.20 \\
\hline
\end{tabular}

$\mathrm{OD}_{550}$ is the absorbance of the bacteria liquid

Comparison of two immobilization methods.

The physical properties of microspheres were obtained in Table 2. Two kinds of microspheres were observed under microscope after being put in red ink for 15min. Mechanical strength of IM2 was obvious larger than that of IM1, therefore, IM2 was able to withstand more impact force of water flow without easily swelling. From the degradation effect, IM1 was slightly better than IM2, but IM1 swelled in the degradation process while IM2 did not, in addition, IM1 was more complicated than IM2. According to the results above, direct immobilization method was chose to make microspheres in this experiment.

Table 2. Performance comparison with two immobilized methods making microspheres

\begin{tabular}{lllll}
\hline Methods & Elasticity and shape & $\begin{array}{l}\rho / g . \\
\mathrm{mL}-1\end{array}$ & $\begin{array}{l}\text { Mecha } \\
\text { nical g }\end{array}$ & $\begin{array}{l}\text { Degradation } \\
\text { rate/\% }\end{array}$ \\
\hline 1 & $\begin{array}{l}\text { Irregular in shape, with a small } \\
\text { amount of a block, soft } \\
\text { regular in shape, without link }\end{array}$ & 21 & 66 \\
2 & \begin{tabular}{l} 
aggregated, hard \\
\hline
\end{tabular}
\end{tabular}

\section{Optimization of immobilization conditions.}

As $\mathrm{pH}$ value was equal to isoelectric point, to reduce surface free energy, microorganism tended to adsorb on the surface of the carrier to new stability [7]. Regulated $\mathrm{pH}$ values of cross linking agent respectively to 3, 4, 5, 6, 7 with $1 \mathrm{~mol} / \mathrm{L}$ of $\mathrm{HCl}$ and $\mathrm{NaOH}$ solution, the experimental results were shown in Table 3. Density of all five kinds of microspheres were larger than that of water, mass transfer was good, the degradation rate increased with the increase of $\mathrm{pH}$ value of cross linking agent, slightly swelled with microspheres after degradation for 5 days when $\mathrm{pH}$ value was in the range of 6-7. Therefore, $\mathrm{pH}$ 5-6 was selected of cross linking agent. 
Table 3. The effect of $\mathrm{pH}$ of cross linking agent $(\mathrm{CaCl} 2,4 \%)$ on the properties of microspheres

\begin{tabular}{llllll}
\hline $\mathrm{pH}$ & Elasticity & $\rho / g \cdot \mathrm{mL}-1$ & $\begin{array}{l}\text { Mechanical } \\
\text { strength/g }\end{array}$ & $\begin{array}{l}\text { radius/ } \\
\mathrm{mm}\end{array}$ & $\begin{array}{l}\text { Degradation } \\
\text { rate/\% }\end{array}$ \\
\hline 3 & hard & 1.19 & 30 & 4 & 46.2 \\
4 & hard & 1.09 & 32 & 3 & 51.4 \\
5 & hard & 1.16 & 30 & 3 & 66.7 \\
6 & Softer than pH5 & 1.06 & 25 & 3 & 75.4 \\
7 & soft & 1.05 & 25 & 3 & 72.1 \\
\hline
\end{tabular}

Inoculation amount directly impacted on immobilization bacteria amount in immobilized microspheres. Rrepared M4 seed bacteria liquid for 2.0, 4.0, 6.0, 8.0, $10.0 \mathrm{~mL}$, washed for 3 times with sterile distilled water after centrifuging, then mixed with $5.0 \mathrm{~mL}$ sterile water to form bacteria solution in a certain concentration, fixed with SA/activated carbon by immobilization method. It can be concluded from the experimental results (see Table 4) that the degradation rate increased with the increase of the amount of immobilized bacteria. When immobilization bacteria reached $8 \mathrm{~mL}$, white floccus appeared during the cross linking process. That may be the reason of too much bacteria in the solution, which caused swelling while cross linking with SA. The mechanical strength of microspheres was significantly decreased when the immobilization bacteria reached $8 \mathrm{~mL}$. After 5 days degradation, microspheres swelled as up to $8 \mathrm{~mL}$ and above. Consequently, the best immobilization bacteria amount was $6 \mathrm{~mL}$.

Table 4. Effect of volume of immobilization bacteria liquid on properties of microspheres

\begin{tabular}{lllll}
\hline $\begin{array}{l}\text { volume } \\
(\mathrm{mL})\end{array}$ & Elasticity & $\begin{array}{l}\text { Mechanical } \\
\text { strength }(\mathrm{g})\end{array}$ & $\begin{array}{l}\text { Mass } \\
\text { transfer }\end{array}$ & $\begin{array}{l}\text { Degradation } \\
\text { rate }(\%)\end{array}$ \\
\hline 2 & hard & 23 & good & 15 \\
4 & softer & 30 & good & 67 \\
6 & softer & 30 & good & 80 \\
8 & soft & 22 & good & 85 \\
10 & soft & 18 & good & 92 \\
\hline
\end{tabular}

\section{Effect of inorganic salts on the properties of microspheres.}

In the liquid phase, ionic strength has an obvious effect on adhering to microorganism [8]. Prepare a certain concentration of M4 bacteria liquid respectively with sterile water and sterile inorganic salt solution, immobilized by SA/diatomite direct immobilization method. As can be seen from table 5, the addition of inorganic salts on the physical properties was not greatly affected. After three days' degradation, the degradation rate of organic matter reached to $52 \%$ by microspheres containing inorganic salt. However, it was only $29 \%$ by that without inorganic salt.

Table 5 Effect of inorganic salts on the properties of microspheres

\begin{tabular}{|c|c|c|c|c|c|}
\hline \multirow[t]{2}{*}{ Microspheres } & \multirow[t]{2}{*}{ elasticity } & \multirow[t]{2}{*}{$\begin{array}{l}\text { Mechanical } \\
\text { strength/g }\end{array}$} & \multirow[t]{2}{*}{$\begin{array}{l}\text { Mass } \\
\text { transfer }\end{array}$} & \multicolumn{2}{|c|}{$\begin{array}{l}\text { Degradation } \\
\text { rate/\% }\end{array}$} \\
\hline & & & & $3 d$ & $5 d$ \\
\hline With inorganic salt & hard & 30 & good & 52 & 73 \\
\hline Without inorganic sa & soft & 28 & good & 29 & 70 \\
\hline
\end{tabular}

\section{Surface structure before and after degradation of immobilized microspheres.}

As can be seen from the SEM (Figure 2 (a)), before degradation, microspheres of SA/diatomite has immobilized a lot of diatomite on their surfaces, which can accelerate the absorption of organic compound in the water, provide raw materials for microbial growth, and accelerate the degradation of organic matter. At the same time, the surface was porous and with sags and crests, which provided the conditions for the microorganism immobilization. According to Figure 2 (b), it attached a layer of matter to the surface of diatomite after degradation, which may be the microbial metabolites produced in the growth and the degradation process of organic matter. Meanwhile, 
cellular structure on its surface was more obvious after degradation. This demonstrated microspheres' high mechanical strength and endurance ability to the impact of water.

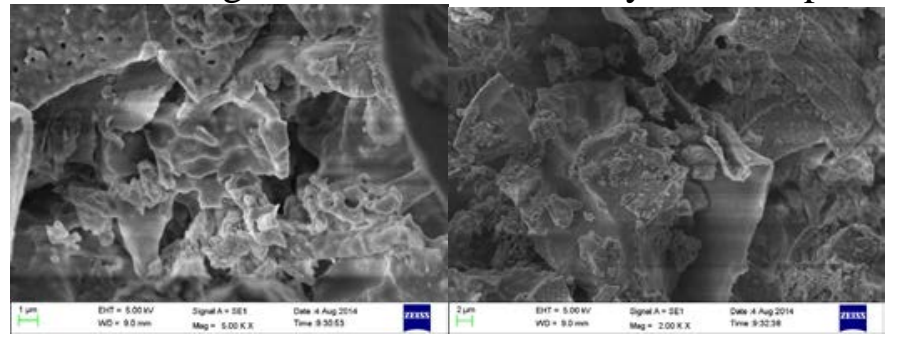

Figure 2 SEM photo before and after degradation of immobilized microspheres

\section{Effects of pH, salinity of immobilized M4 on degradation of spilled-oil.}

As seen from Figure 3, the suitable $\mathrm{pH}$ value on degradation of free $\mathrm{M} 4$ was 7-8, the degradation rate was 40\%; while the immobilized M4 could well grow in $\mathrm{pH}$ range of 6-9, the highest degradation rate could reach $75 \%$. When $\mathrm{pH}$ was over 8 , the degradation rate has been significantly reduced.

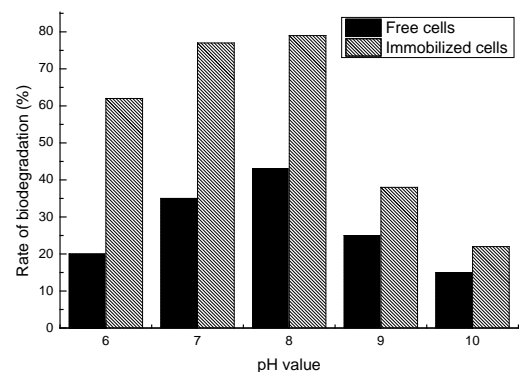

Figure 3 Effect of $\mathrm{pH}$ on organic matter degradation rate

According to experimental results, the optimum salinity range was 3\%- $4 \%$ for free M4 and immobilized M4. But If the adaptive range to salinity of immobilized M4 widened to 2\%- 5\%, the highest degradation rate could reach above $70 \%$, while for the free M4, it could reach only about $40 \%$.

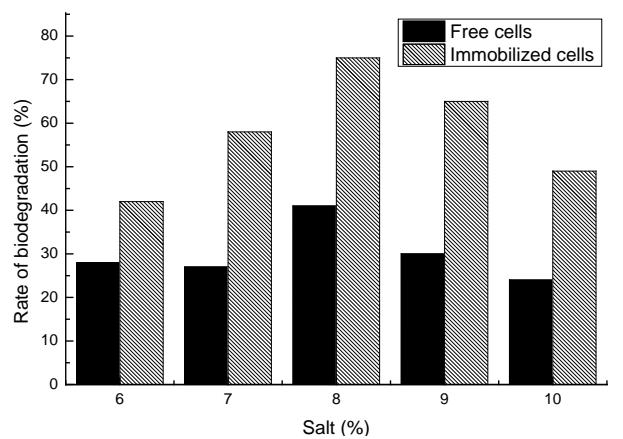

Figure 4 Effects of salinity on organic matter degradation rate

\section{Conclusion}

The dynamic adsorption of bacteria M4 could reach the saturation with diatomite carrier material in 6 hours at $25^{\circ} \mathrm{C}$, and the maximum adsorption capacity was $11.1 \times 10^{8} \mathrm{CFU} / \mathrm{g}$. With SA/diatomite immobilizing M4, the prepared microspheres using direct immobilization method and immobilization after adsorption method. The physical properties and degradation rate of organic matter on both prepared microspheres, we could conclude that direct immobilization method is better. At the temperature of $25{ }^{\circ} \mathrm{C}$ for 24 hours' cross linking, it was showed that the best $\mathrm{pH}$ of cross linking agent is 5-6, the volume ratio of immobilization bacteria liquid and gel solution is 1:5. The addition of inorganic salt could raise the activities of immobilized M4. SEM was observed before and after degradation, which showed that immobilized microspheres have good properties. 
The highest degradation rate reached $40 \%$ for free M4, while $70 \%$ for immobilized M4, which increased over $30 \%$ after immobilized by SA/diatomite carrier material.

\section{Acknowledgements}

This research was supported by the funds of Shandong Natural Science Foundation Project (ZR2014JL038); Projects of Medical and Health Technology Development Program (2014WS0281), Shandong, China.

\section{References}

[1] Seung-Woo Jeong et al. 2015. Simple surface foam application enhances bioremediation of oilcontaminated soil in cold conditions. Journal of Hazardous Materials. 286:164-170.

[2] Saranya Kuppusamy et al. 2015. Bioremediation potential of natural polyphenol rich green wastes: A review of current research and recommendations for future directions. Environmental Technology \& Innovation. 214:11-26.

[3] Han Xie et al. 2015. Fabrication of a novel immobilization system and its application for removal of anthracene from soil. Biochemical Engineering Journal. 97:8-16.

[4] K.A. Mackie et al. 2015. The effects of biochar and compost amendments on copper immobilization and soil microorganisms in a temperate vineyard. Agriculture, Ecosystems \& Environment. 201:58-69.

[5] Wen-Wei Li et al. 2015. Stimulating sediment bioremediation with benthic microbial fuel cells. Biotechnology Advances. 33: 1-12.

[6] Zhang, S.J. et al. 2014. Screening and characterization of biodegradation microorganism from beach oil spill. China Science and Technology Information. 3, 38-39.

[7] Filip Ruzicka et al. 2010. The differences in the isoelectric points of biofilm-positive and biofilm-negative Candida parapsilosis strains. Journal of Microbiological Methods. 80(3): 299301.

[8] Thomas Scherr et al. 2015. Computational fluid dynamics as a tool to understand the motility of microorganisms. Computers \& Fluids. 114:274-283. 